\title{
РОЗДІЛ II
}

\section{Конституційне, адміністративне, інформаційне та міэснародне право}

УДК 347.921-021.23:341.645

DOI https://doi.org/10.32782/2409-4544/2020-1/5

К. Музичук

\section{Принцип процесуальної справедливості (процесуальної рівності) та принцип рівності сторін у практиці Свропейського суду з прав людини}

У статті розглядається тлумачення принципу процесуальної справедливості (процесуальної рівності) та принципу рівності сторін, вироблених ЄСПЛ та їх значення для вітчизняних судів. Серед вироблених ЄСПЛ принципів відстоювання прав людини - принцип процесуальної справедливості (або процесуальної рівності). На цей принцип Суд посилається тоді, коли в справі фігурує значне число свідків. Принцип рівності сторін у судовому розгляді. полягає в забезпеченні однакових умов сторонам у судовому процесі (зокрема, особі та державі) i, на думку ЄСПЛ вимагає, щоб кожній стороні надавалася розумна можливість представити справу в таких умовах, які не ставлять цю сторону в суттєво невигідне становище відносно другої сторони. Згаданий принцип ЄСПЛ визначає як один із складників ширшої концепції справедливого судового розгляду: кожній стороні має бути надана можливість представити свою справу за умов, що не ставлять сторону в невигідне становище по відношенню зі своїм оппонентом.Показано, що впровадження згаданих принципів у вітчизняну практику судочинства, поряд з іншими принципами ЄСПЛ, сприяє забезпеченню безпомилковості прийнятих судами рішень та невідворотності від демократизації судочинства. Приділено увагу еволюційному розвитку згаданих принципів відповідно до сьогодення. Запропоновано блок-схеми, які ілюструють значення згаданих принципів у судовому процесі. Наведено конкретні приклади із практики ЄСПЛ щодо застосування згаданих принципів. Особлива увага приділяється використанню судами показань у кримінальному провадженні, анонімним свідченням, отриманим на досудовому етапі провадження та використанні їх судами.

Ключові слова: ЄСПЛ, судова практика, принцип процесуальної справедливості, принцип рівності сторін у судовому розгляді, демократія.

Постановка наукової проблеми та її значення. Обрання Україною стратегічного курсу на набуття рівноправного членства в Свропейському Союзі викликає потребу у здійсненні демократизації судочинства. Від дотримання та ефективного захисту прав людини залежить стан демократії в державі, а оскільки захист прав і свобод людини є прерогативою суду, то очевидною постає проблема реформування вітчизняного судочинства на основі принципів демократії. Справедливість зробленого висновку доведена багаторічною практикою: основоположні свободи, які становлять підвалини справедливості та миру в усьому світі, найкращим чином забезпечуються завдяки дієвій демократії [1, Преамбула]. Принципи демократії сформовані практикою Європейського суду з прав людини (далі - ЄСПЛ або Суд) і вони лежать в основі безпомилкових рішень цієї наднаціональної судової інстанції.

Аналіз досліджень цієї проблеми. Практика ЄСПЛ сформувала низку демократичних принципів, які все частіше беруться на озброєння вітчизняними судами. Все більше суддів усвідомлюють, що дотримання демократичних принципів захисту прав і основоположних свобод людини сприяє безпомилковості у рішеннях суду. Проблема вивчення тлумачень демократичних принципів, вироблених ЄСПЛ не $\epsilon$ новою, ії піднімали як науковці, так і судді. Підняту проблему

(C) Музичук K., 2020 
розглядали: $\quad$ В. Г. Буткевич, $\quad$ В. В. Долежан, І. П. Домбровський, $\quad$ А. І. Ковлер, Ж.-П. Коста, В. І. Манукян, А. А. Стрижак, В. М. Шаповал, С. В. Шевчук, Г. Ю. Юдківська. Потреба дослідження демократичних принципів, сформованих ЄСПЛ, не втратила актуальності на даний час. Причиною цього $\epsilon$ те, що згадані принципи не $\epsilon$ закостенілими, а еволюціонують відповідно до вимог сьогодення. Щоб унеможливити будь-який відхід від демократії, забезпечити відповідність судових рішень вітчизняних судів тим, які б прийняв ЄСПЛ, проблема потребує подальшого наукового дослідження.

Формулювання мети та завдань статті. Метою статті є аналіз позиції ЄСПЛ щодо демократичних принципів судочинства.

Відповідно до цієї мети завданнями статті є:

1) розкрити правову суть принципів процесуальної справедливості (процесуальної рівності) та рівності сторін у судовому розгляді;

2) показати демократичний характер згаданих принципів, їх значення у процесуальному розгляді справ під час відстоювання основоположних прав і свобод людини;

3) прослідкувати еволюційний (з часом) розвиток кожного з цих принципів.

Виклад основного матеріалу й обгрунтування отриманих результатів дослідження. Серед вироблених ЄСПЛ принципів відстоювання прав людини - принцип процесуальної справедливості (або процесуальної рівності). На цей принцип Суд посилається тоді, коли в справі фігурує значне число свідків. Правове обгрунтування того, що принцип процесуальної справедливості відноситься до демократичних, вдалось встановити на основі вивчення практики ЄСПЛ. Зокрема, з'ясовано, що під час процесуального розгляду Суд дотримується алгоритму: 1) право відбору певного числа свідків надається державі-відповідачеві (ССПЛ розглядає позови громадян чи недержавних організацій проти держави, або одних держав проти інших); 2) Комісія (йдеться про Європейську комісію з прав людини - К.М.) не проти збільшення числа свідків у справі; число свідків визначається значенням наведених доказів на момент заслуховування свідків; 3) Комісія не проти збільшення числа свідків, якщо держава-відповідач на цьому енергійно настоює; 4) умови відбору свідків пропонуються без притиску однієї зі сторін, добровільно, виважено, відповідно до стану справи [2].

Принцип процесуальної справедливості можна ілюструвати блок-схемою, наведеною на рис. 1.

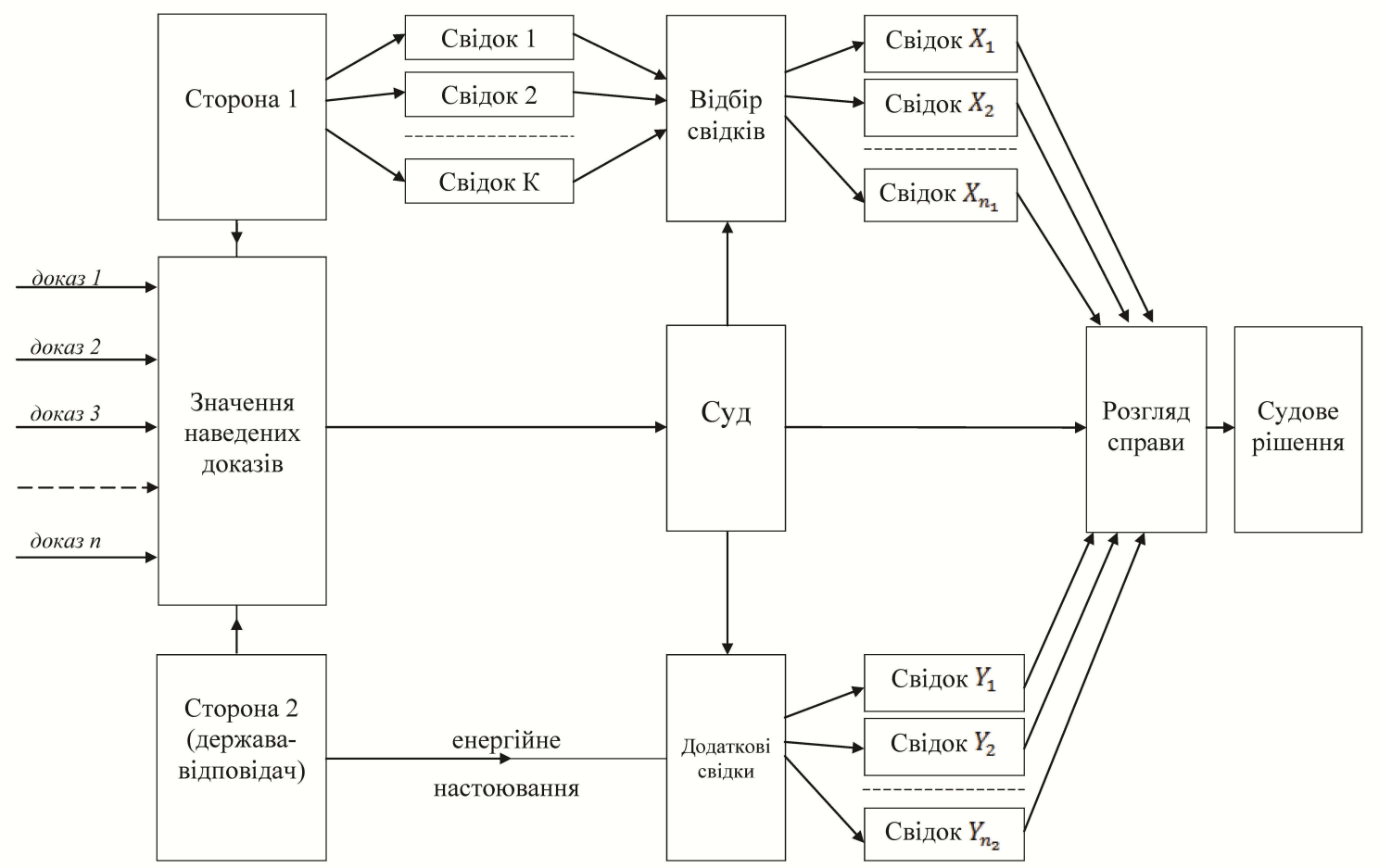

Рис. №1. Практика Суду, яка відображає принцип процесуальної справедливості (процесуальної рівності)

До принципів, яких дотримується Суд у процесуальному розгляді справ під час відстоювання основоположних прав і свобод людини, належить і принцип рівності сторін у судовому розгляді. Демократизм згаданого принципу полягає в забезпеченні однакових умов сторонам у судовому 
процесі (зокрема, особі та державі) i, на думку Суду «вимагає, щоб кожній стороні надавалася розумна можливість представити справу в таких умовах, які не ставлять цю сторону в суттєво невигідне становище відносно другої сторони» [3, п.38]. Згаданий принцип Суд визначає як один із складників ширшої концепції справедливого судового розгляду: кожній стороні має бути надана можливість представити свою справу за умов, що не ставлять сторону в невигідне становище по відношенню зі своїм опонентом [4]. У даному випадку Суд переходить від вислову «передбачає» до більш жорсткого вислову «вимагає», що підсилює обов'язковість процесуальної міри.

Принцип рівності сторін у судовому розгляді можна ілюструвати блок-схемою, наведеною на рис. 2. Із блок-схеми видно, що вирівнювання умов щодо представлення справи, $\epsilon$ обов'язковою процесуальною мірою, яка передує судовому розгляду. Ця міра зводиться до того, щоб кожна зі сторін могла представити власне бачення, без створення невигідних умов іншій стороні. Розумність представлення справи кожною зі сторін регулюється національними судами.

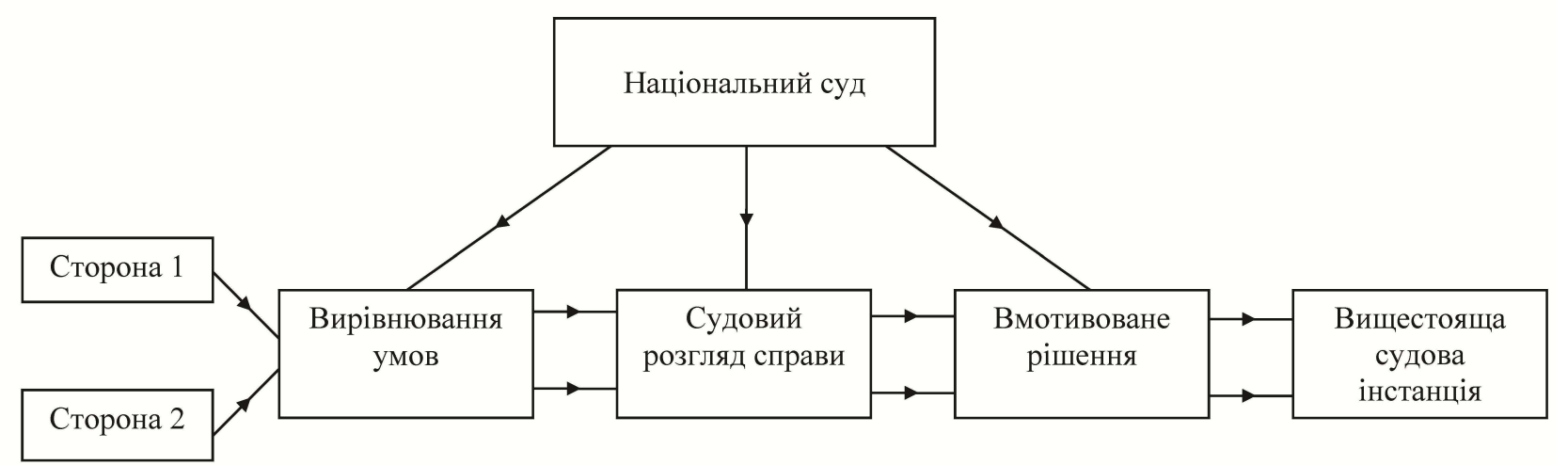

Рис. №2. Практика Суду, яка відображає принцип рівності сторін у судовому розгляді

Принцип процесуальної справедливості і принцип рівності сторін у судовому розгляді не зводяться до констатації сказаного. Кожен із них знаходить розвиток у конкретних справах ЄСПЛ, про що йтиме мова нижче.

Процедура обмеження значного числа свідків у справі носить демократичний характер, адже встановлює справедливі умови для обох сторін. Як відзначив Суд, «питання прийняття доказів регулюється, насамперед, національним законодавством ... Завдання Європейського суду полягає не в тому, щоб винести постанову про те, чи в належний спосіб заяви свідків було прийнято як докази, а скоріше в тому, щоб з'ясувати, чи було справедливим провадження в цілому, зокрема процедура отримання свідчень» [5, п.50].

У випадку кримінального провадження, «всі свідчення мають бути оприлюднені у відкритому розгляді, у присутності обвинувачених, яким забезпечується можливість участі у змагальному процесі. 3 цього правила можуть бути винятки, але вони не повинні обмежувати прав захисту, передбачених пунктами 1 та 3(d) статті 6 (йдеться про Конвенцію про захист прав людини та основоположних свобод [1], далі - Конвенція). А саме: підсудний має право оспорювати докази, надані свідком обвинувачення, допитати його під час слухання або вимагати допиту цього свідка на пізнішому етапі» [6, п.49].

Зміст згаданих конвенційних норм статті 6 у наступному:

«1. Кожен має право на справедливий і публічний розгляд його справи упродовж розумного строку незалежним і безстороннім судом, встановленим законом, який вирішить спір щодо його прав та обов'язків цивільного характеру або встановить обгрунтованість будь-якого висунутого проти нього кримінального обвинувачення. Судове рішення проголошується публічно, але преса і публіка можуть бути не допущені в зал засідань протягом усього судового розгляду або його частини в інтересах моралі, громадського порядку чи національної безпеки в демократичному суспільстві, якщо того вимагають інтереси неповнолітніх або захист приватного життя сторін, або - тією мірою, що визнана судом суворо необхідною, - коли за особливих обставин публічність розгляду може зашкодити інтересам правосуддя.

3(d).допитувати свідків обвинувачення або вимагати, щоб їх допитали, а також вимагати 
виклику й допиту свідків захисту на тих самих умовах, що й свідків обвинувачення» [1].

Суд допускає використання анонімних свідчень, отриманих на досудовому етапі провадження. Сказане підтверджується наступним: «Згідно із принципом змагального судового процесу, всі докази мають пред’являтися у присутності обвинуваченого на відкритому слуханні [7, п.78]. Це не означає, однак, що, для того щоб показання свідків були використані як доказ, вони завжди мають бути оголошені на відкритому слуханні в суді: використання як доказів таких показань, взятих на досудовому етапі провадження, саме по собі не суперечить пункту 3(d) та пункту 1 статті 6 , якщо при цьому дотримано гарантій прав сторони захисту» [5, п. 41].

Іншими прецедентами Суд обгрунтовує допустимість розгляду анонімних свідчень тим, що життя, право на свободу та особисту недоторканість можуть наражатися на ризик, як і інтереси, обумовлені у статті 8 Конвенції (про повагу до приватного і сімейного життя). «Зазначені інтереси свідків та потерпілих у принципі захищені іншими положеннями Конвенції, які вимагають від договірних держав організовувати своє кримінальне судочинство в такий спосіб, щоб не піддавати їх невиправданому ризику. Крім того, згідно з принципами справедливого судового розгляду, у відповідних випадках інтереси захисту мають урівноважуватися інтересами свідків або потерпілих, яких викликано давати свідчення» [8, п. 70; 9, п. 53].

У випадку, коли свідки обвинувачення виступають анонімно, перед захистом постають труднощі, яких загалом не повинно бути у кримінальному судочинстві. На думку Суду, «у таких випадках, згідно 3 пунктами 1 та 3(d) статті 6 Конвенції, невигідні умови, які таким чином створюються для захисту, мають урівноважуватися дотриманням судовими органами спеціальних процедур» [8, п.72; 9, п.55]. Суд не допускає засудження на основі лише анонімних свідчень. Підтвердження: «Нарешті засудження не має грунтуватися ні виключно, ні переважно на анонімних заявах» $[8$, п.76; 9, п.55].

Висновки та перспективи подальшого дослідження. У процесі дослідження вдалось обгрунтувати потребу в принципі процесуальної справедливості та принципі рівності сторін у судовому розгляді для вітчизняного судочинства. Їх впровадження у судочинство України сприятиме безпомилковості в роботі судів, а значить, демократизації вітчизняного судочинства.

На перспективу подальших розвідок можна віднести дослідження еволюційних тлумачень ЄСПЛ згаданих демократичних принципів.

\section{Джерела та література}

1. Конвенція про захист прав людини і основоположних свобод з поправками, внесеними згідно до положень Протоколів №№ 11 та 14 з протоколами №№ 1, 4, 6, 7, 12 та 13. - Страсбург: Секретаріат Європейського суду з прав людини, 2010. - 24 с.

2. Рішення Великої палати ЄСПЛ від 10 травня 2001 року у справі «Кіпр проти Туреччини» [Chypre v. Turkey] [GC] (заява № 25781/94).

3. Рішення ЄСПЛ від 23 жовтня 1996 року у справі «Анкерл проти Швейцарії» [Ankerl v. Switzerland] (заява № 17748/91).

4. Рішення Великої палати ССПЛ від 7 червня 2001 року у справі «Кресс проти Франції» [Kress v. France] [GC] (заява № 39594/98).

5. Рішення ЄСПЛ від 20 листопада 1989 року у справі «Костовський проти Нідерландів» [Kostovski v. The Netherlands] (заява № 43489/20).

6. Рішення ССПЛ від 15 червня 1992 року у справі «Люді проти Швейцарії» [Lüdi v. Switzerland] (заява № 12433/86).

7. Рішення ЄСПЛ від 13 червня 1994 року у справі «Барбера, Месеже і Жобардо проти Іспанії» [Barbera, Messegue and Jabardo v. Spain] (заява № 10590/83).

8. Рішення ЄСПЛ від 26 березня 1996 року у справі «Дорсон проти Нідерландів» [Doorson v the Netherlands] (заява № 20524).

9. Рішення ЄСПЛ від 23 квітня 1997 року у справі «Ван Мехелен та інші проти Нідерландів» [Van Mechelen and Others v. Netherlands] (заяви № 55/196/674/861-864).

Музычук К.. Принцип процессуальной справедливости (процессуального равенства) и принцип равенства сторон в практике Европейского суда по правам человека. В статье рассматривается толкование принципа процессуальной справедливости (процессуального равенства) и принципа равенства сторон, производимых Европейским судом по правам человека (ЕСПЧ) и их 
значение для отечественных судов. Среди сформулированных ЕСПЧ принципов отстаивание прав человека - принцип процессуальной справедливости (или процессуального равенства). На этот принцип ЕСПЧ ссылается тогда, когда в деле фигурирует значительное число свидетелей. Принцип равенства сторон в судебном разбирательстве. заключается в обеспечении равных условий сторонам в судебном процессе (в частности, заявителю и государству) и, по мнению ЕСПЧ необходимо, чтобы каждой стороне предоставлялась разумная возможность представить дело в таких условиях, которые не ставят эту сторону в существенно невыгодное положение относительно другой стороны. Упомянутый принцип ЕСПЧ определяет как одну из составляющих более широкой концепции справедливого судебного разбирательства. Показано, что внедрение упомянутых принципов в отечественную практику судопроизводства, наряду с другими принципами ЕСПЧ, способствует обеспечению безошибочности принятых судами решений и неотвратимости от демократизации судопроизводства. Уделено внимание эволюционному развитию упомянутых принципов. Предложены блок-схемы, иллюстрирующие значение упомянутых принципов в судебном процессе. Приведены конкретные примеры из практики ЕСПЧ по применению упомянутых принципов. Особое внимание уделяется использованию судами показаний в уголовном производстве, анонимным свидетельствам, полученным на досудебном этапе производства и использовании их судами.

Ключевые слова: ЕСПЧ, судебная практика, принцип процессуальной справедливости, принцип равенства сторон в судебном разбирательстве, демократия.

Muzychuk K. The Principle of Procedural Justice (Procedural Equality) and the Principle of Equality of the Parties: the European Court of Human Rights Practice. The article highlights the interpretation of the principle of procedural justice (procedural equality) and the principle of equality of arms issued by the European Court on Human Rights (ECtHR) and their significance for the Ukrainian courts. The author argues that the implementation of these principles in the national practice of justice, along with other principles of the ECtHR, contributes to ensuring the court decisions accurateness and makes the democratization of justice inevitable. The study focuses on the evolutionary development of these principles in terms of current trends in the judiciary. The block diagrams illustrate the importance of these principles for legal proceedings. The specific examples of these principles implication in the practice of the European Court on Human Rights contribute to a better understanding of their importance. Among the principles of human rights advocacy developed by the is the principle of procedural justice (or procedural equality). This principle is invoked by the Court when a significant number of witnesses are involved in the case. The principle of equality of parties in court proceedings. is called to ensure a level of equal conditions for the parties during the proceedings (in particular, the individual and the State). ECHR considers that this principle requires a reasonable opportunity for party to present the case in a side that does not place the other party at a significantly disadvantage position relative to the other party. This principle is defined by the ECHR as one of the components of a broader concept of a fair trial: each party should be given the opportunity to present its case under conditions that do not put the party at a disadvantage position relative its opponent. Special attention is paid to the testimony used by the courts in criminal proceedings, witness' anonymous testimony obtained at the pre-trial stage of proceedings, and their usage by the court.

Key words: ECtHR, judicial practice, principle of procedural justice, principle of equality of parties in court proceedings, democracy. 